\begin{tabular}{|c|c|c|}
\hline $\begin{array}{l}\text { RESEARCH } \\
\text { ARTICLE }\end{array}$ & $\begin{array}{r}\text { ADVANCE RESEARCH JOURNAL O } \\
\text { Volume } 6 \text { | Issue } 2 \text { | December, } 2015 \mid 258-260\end{array}$ & $\begin{array}{l}\text { F SOCIAL SCIENCE } \\
\text { e ISSN-2231-6418 }\end{array}$ \\
\hline $0=$ & DOI: 10.15740/HAS/ARJSS/6.2/258-260 & Visit us : www.researchjournal.co.in \\
\hline
\end{tabular}

\title{
Participation of rural women in vegetable production
}

Anuradha Ranjan Kumari* and Laxmikant ${ }^{1}$

Krishi Vigyan Kendra (IIVR), Malhana, DEORIA(U.P.) INDIA

(Email : anuradha_rau@ rediffmail.com)

${ }^{1}$ Krishi Vigyan Kendra (SVPUA\&T), RAMPUR (U.P.) INDIA

\section{ARTICLE INFO :}

$\begin{array}{lll}\text { Received } & : & 13.10 .2015 \\ \text { Revised } & : & 19.11 .2015 \\ \text { Accepted } & : & 26.11 .2015\end{array}$

KEY WORDS :

Rural women, Participation, Vegetable production

\section{HOW TO CITE THIS ARTICLE :}

Kumari, Anuradha Ranjan and Laxmikant (2015). Participation of rural women in vegetable production. Adv. Res. J. Soc. Sci., 6 (2) : 258-260.

\begin{abstract}
Women play a significant and crucial role in vegetable production. It is most unfortunate that the role of women and their contribution in farm activities are get to be recognized. Although they perform almost all the activities in the farm but by and large they have been remained as invisible workers. The study was conducted in Salempur and Bhatpar Rani Blocks of Deoria district in Uttar Pradesh to ascertain women participation in vegetable production. 120 house having land for vegetable cultivation were selected. 60 rural women from 60 houses selected from each block. Female respondents from each house were interviewed. The data were collected personally through structured interview schedule. Data collected included the extent of participation and decision making of women in various activities of vegetable production. Study revealed that in vegetable cultivation various intervention points are addressable. Women were involved in operations such as cleaning of land, sowing of seed, transplanting of vegetable nursery, hoeing and weeding, scaring of birds and rodents, harvesting and processing of vegetable and storage of seed. The non participation of women in various operations is due to high fatigueless, requirement of more muscle power, lack of knowledge and awareness with respect to decision making. It is observed that women played only supportive role less participation of women in decision making could be attributed to custom, tradition social barrier, their illiteracy ignorance and less participation in extension programmes. Women education, technical training and adequate extension facilities can create a positive impact leading to a better tomorrow.
\end{abstract}

